\title{
Sensory response and physical characteristics of gluten-free and gum-free bread with chia flour
}

\author{
Katira da Mota HUERTA ${ }^{1 *}$, Jamila dos Santos ALVES ${ }^{1}$, Ariádni Franco Coelho da SILVA, \\ Ernesto Hashime KUBOTA², Claudia Severo da ROSA²
}

\begin{abstract}
The aim of this study was to evaluate the physical quality and sensory acceptance of gluten-free breads with different percentages of chia flour (Salvia Hispanica L.). The chia flour was used to substitute rice flour and soy flour in order to replace the gum required in this type of bread. Four formulations were developed; a standard made with gum, and three formulations with $2.5 \%$, $5.0 \%$ and $7.5 \%$ of chia flour. Analyses of specific volume, cooking losses and the rise in dough of the breads were performed. Sensory analysis included tests for affective acceptability and purchase intent. The results showed that the bread with $2.5 \%$ chia flour had specific volume and cooking losses similar to the standard. In terms of the rise in dough, the standard showed the highest values, followed by the bread made with $5.0 \%$ chia flour. The substitution of soy and rice flour with $2.5 \%$ of chia flour produced bread with sensory characteristics similar to the standard in all of the analyzed attributes; it also received higher purchase intent. Using chia flour at a concentration of $2.5 \%$, compared to rice flour and soy flour, proved that it was possible to replace gum in the bread formulation.
\end{abstract}

Keywords: celiac disease; chia; HPMC gum.

Practical Application: Chia flour (2.5\%) gives physical characteristics to bread which are similar to bread made with gum.

\section{Introduction}

Celiac disease is caused by a permanent intolerance to the gluten proteins which are present in cereals like wheat, rye and barley. Rice and soy flours are frequently used to replace flour made from cereals (Atzingen \& Silva, 2001). However, this substitution adversely affects the nutritional, technological and sensory characteristics of products because flours without gluten are often refined, and when they are mixed to form dough they do not form a structure or a continuous phase, which results in low-quality bread (Andrade et al., 2011). Much research has been conducted to improve the quality of gluten-free breads, and additives such as gums and emulsifiers are very often used. However, there have been some promising studies aimed at using gluten-free raw materials with high nutritional value, which also contribute to the improvement of the physical characteristics of products. Because chia flour is a source of nutrients and mucilage and also does not contain gluten, it has been used in such preparations (Figueira et al., 2011; Garda et al., 2012). Chia (Salvia Hispanica L.) is of particular interest because it contains high levels of fiber, proteins, minerals and polyunsaturated fatty acids (Uribe et al., 2011). In the presence of water, chia exudes a transparent, mucilaginous gel which has emulsifying properties; this gel can be used as emulsifier in baked products (Garda et al., 2012). The aim of this study was to evaluate the physical quality and sensory acceptance of gluten-free breads with different added percentages of chia flour (Salvia Hispanica) to replace rice and soy flour in an attempt to replace the gum required in this type of bread.

\section{Materials and methods}

\subsection{Raw materials}

The ingredients used in the formulation of the breads were as follows: rice flour, which was donated by the Favarin company (Santa Maria, RS); Pra vida ${ }^{\circledR}$ soy flour; Cia Natural ${ }^{\circledR}$ chia flour; Cisne ${ }^{\circledR}$ refined salt; Fleischman ${ }^{\circledR}$ freeze-dried yeast; Sadia ${ }^{\circledR}$ lite margarine with $38 \%$ lipids; União ${ }^{\circledR}$ refined sugar; water; and Genix ${ }^{\circledR}$ HPMC (hydroxypropyl methylcellulose) gum. With the exception of the rice flour, all the ingredients were acquired commercially in the city of Santa Maria, RS, Brazil.

\subsection{Development of formulations}

The basic formulation of the breads was defined by the pre-tests developed by Moreira (2007). A standard formulation was prepared without chia flour and gum. In order to verify the action of chia flour as a gum, three treatments were prepared, which presented partial substitution of the base mixture of flours (rice or soy) by chia flour in the proportions of $2.5 \%$ (T1), 5.0\% (T2) and 7.5\% (T3); these three formulations were without HPMC gum. The formulations used in this study are presented in Table 1 
Table 1. Formulations used in the preparation of gluten-free breads with chia flour and without gum.

\begin{tabular}{lcccr}
\hline \multicolumn{1}{c}{ Ingredients } & Standard (\%) & Treatment 1 (\%) & Treatment 2 (\%) & Treatment 3 (\%) \\
\hline Rice flour & 33.83 & 32.98 & 32.13 & 31.28 \\
Soy flour & 8.44 & 8.24 & 8.03 & 7.82 \\
Chia flour & 0.00 & 1.05 & 2.11 & 3.17 \\
Refined salt & 0.85 & 0.85 & 0.85 & 0.85 \\
Refined sugar & 1.27 & 1.27 & 1.27 & 1.27 \\
Freeze-dried biological yeast & 1.69 & 1.69 & 1.69 & 1.69 \\
Gum (HPMC) & 0.64 & 0.00 & 0.00 & 0.00 \\
Lipids (lite margarine) & 2.54 & 2.54 & 2.54 & 5.54 \\
Water & 50.74 & 50.74 & 50.74 & 50.74 \\
\hline
\end{tabular}

Source: Moreira (2007) with modifications. ${ }^{*}$ Substitution levels of rice flour and soy flour by chia flour: T1 (1:05\% equals $2.5 \%$ compared to mixed flour base); T2 (2:11\% equals 5.0\% compared to mixed flour base); T3 (3.17\% equals $7.5 \%$ compared to mixed flour base).

\subsection{Processing of the breads}

The breads were prepared in a bakery located in the city of Caçapava do Sul, RS, Brazil, using the "direct dough" method, which is based on mixing all the ingredients in a single phase (without fermentation). This stage was carried out manually (approximately 5 minutes) until a smooth, homogeneous dough was achieved; similar to a cake but firmer and more consistent. The weight of the raw dough placed in each mold was $116 \mathrm{~g}$ in order to standardize the results. The dough was then poured into equally sized molds $(10 \mathrm{~cm} \times 6 \mathrm{~cm} \times 4.5 \mathrm{~cm})$ and allowed to stand to rise for 50 minutes at room temperature (approximately $25^{\circ} \mathrm{C}$ ). The cooking was performed in a Venâncio industrial oven at an average temperature of $170^{\circ} \mathrm{C}$ for 25 minutes.

\subsection{Analyses}

\section{Cooking losses}

To determine the amount of loss that occurred during cooking the breads, the raw dough was weighed on an analytical balance and then the baked breads were also weighed after cooling for one hour. The method to determine cooking losses followed Equation 1 (Philippi, 2003).

Cooking losses $(g)=$ weight of raw dough $(g)-$ final weight $(g)$

\section{Rise of dough}

To measure this property, the same sized molds were used to bake all the formulations. After having been removed from the molds, the loaves were cut into $1.5 \mathrm{~cm}$ wide slices; the height of the slices was measured with a ruler and expressed in $\mathrm{cm}$, following the methodology proposed by Garda et al. (2012).

\section{Specific volume}

This measurement was performed using the millet seed displacement method. This method is based on the relationship between the volume of the baked bread and its weight, which is obtained by using an analytical balance. The samples were analyzed one hour after they were removed from the oven and the results were expressed in $\mathrm{mL} \cdot \mathrm{g}^{-1}$ and calculated in accordance with Equation 2 (Pizzinatto et al., 1993; El-Dash et al., 2006).
$\mathrm{SV}\left(\mathrm{mL} \cdot \mathrm{g}^{-1}\right)=\frac{\text { volume }(\mathrm{mL})}{\text { weight }(\mathrm{g})}$

Sensory analysis

The affective acceptability test was performed at laboratory level. Fifty testers expressed their level of acceptance using a hedonic seven-point scale ranging from $1=$ extremely disliked to 7 = liked very much (Moreira, 2007). The following five attributes were evaluated: color, aroma, texture, flavor and overall appearance. Before evaluation, the testers were asked to read and sign the terms of a consent form stating that they were not allergic to the ingredients of the formulations. They also agreed to the use of the information for appropriate purposes and that they had the right to withdraw from the tests at any time. The evaluation was carried out in individual booths at the Sensory Analysis Laboratory of the Department of Technology and Food Science at the Center of Rural Sciences at UFSM. The loaves were sliced and a slice of each treatment was identified using random three-digit numbers and presented in a monadic way to the testers. Each tester tasted four samples, which were served sequentially, and received a glass of water to clean the taste buds between each sample. This study was approved by the Research Ethics Committee of the Federal University of Santa Maria; protocol No. 30336014.9.0000.5346.

A purchase intent test was also performed by using a five-point scale ranging from 1 = would certainly not buy to $5=$ would certainly buy, as described by Vasconcelos et al. (2006).

\subsection{Statistical analysis}

The analyses were performed in three repetitions, which are conducted in triplicate. The results were expressed as mean \pm standard deviation and subjected to analysis of variance (ANOVA). The averages were compared by Tukey's test, with a significance level of $95 \%(\mathrm{p}<0.05)$. The results were analyzed using with Statistica version 7.0 software.

\section{Results and discussion}

\subsection{Specific volume, rise in dough, and cooking losses}

Table 2 shows the influence of the chia flour on the specific volume, cooking losses and the rise in dough of the gluten-free breads. 
The results for specific volume for the breads with added chia flour showed no significant difference between them. The standard formulation (with HPMC) was significantly higher compared to these treatments, except for the bread with $2.5 \%$ chia flour, which had a lower ratio of substitution. According to Katina et al. (2006), the addition of fiber in baked goods is considered a benefit, but it can often cause problems in relation to the technological quality of bread, reducing the volume and elasticity of the crumbs. Similar results were found by Rocha \& Santiago (2009) when they evaluated wheat breads with the addition of 25,50 and $75 \%$ of peel and pulp from baru fruit to increase the fiber content; the results of those authors varied between 1.76 and $2.5 \mathrm{~mL} / \mathrm{g}$.

The results for the rise in dough were similar to those for specific volume; the treatments containing chia flour had lower results. The highest value was obtained for the treatment with HPMC $(4.12 \mathrm{~cm})$ and the lowest was for the treatment with $7.5 \%$ chia flour $(3.37 \mathrm{~cm})$.

Losses during cooking are due to the evaporation of liquids, particularly water. Treatments 2 and 3 had the lowest values, differing significantly from the results obtained for the standard bread and the bread with $2.5 \%$ chia flour, the same showed a lower ability to retain water during processing, showing the effect of the chia flour on the water retention of the formulations during cooking.

\subsection{Sensory analysis}

Table 3 shows the average scores for the attributes evaluated in the sensory acceptance tests for the gluten-free breads. It can be seen that most of the evaluations were between 4 and 6 (scores classified as "indifferent" and "liked a lot") apart from the attribute of flavor, which for the breads with 5.0\% and 7.5\% of chia flour received average scores of between 3 and 4 , which corresponded to "disliked" and "indifferent". Some testers also commented that the treatments with the highest percentage of chia flour had a bitter aftertaste, which negatively influenced the perception of the testers regarding this attribute.
The bread with $2.5 \%$ chia flour showed no significant differences in relation to the standard for all the analyzed attributes. Consequently, it can be inferred that the use of chia flour did not affect the acceptability and that its performance as gum was similar to that of HPMC when added in a concentration of $2.5 \%$ relative to the weight of the formulation of the flours. Borges et al. (2011) evaluated the addition of linseed flour in wheat bread and they also found that lower levels of linseed resulted in greater acceptability of the final product. Coelho \& Salas-Mellado (2015) used chia to develop wheat bread and their results showed that acceptance was between the scores that equated to "liked moderately" and "liked very much". The results regarding the purchase intent for the breads in the present study are shown in Figure 1. It can be seen that the bread with 2.5\% chia flour showed the highest purchase intent, reaching $40 \%$, and was represented by the evaluation "would certainly buy". Similar

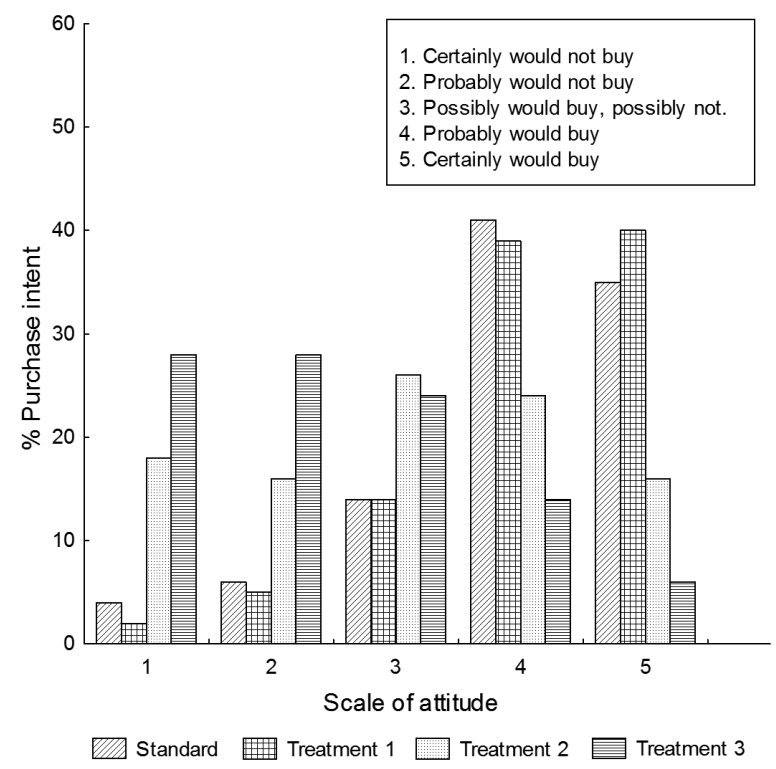

Figure 1. Purchase intent obtained in sensory analysis for all the gluten-free bread formulations. Standard: with HPMC; T1: $2.5 \%$ chia flour; T2: 5.0\% chia flour; T3: 7.5\% chia flour.

Table 2. Results of specific volume, cooking losses and rise in dough obtained for breads with chia flour and without gum.

\begin{tabular}{lcrrr}
\hline \multicolumn{1}{c}{ Physical Characteristics } & Standard & T1 & T2 & T3 \\
\hline Specific volume (mL.g) & $2.61 \pm 0.22^{\mathrm{a}}$ & $2.32 \pm 0.05^{\mathrm{ab}}$ & $2.13 \pm 0.20^{\mathrm{b}}$ & $1.95 \pm 0.12^{\mathrm{b}}$ \\
Cooking losses $(\mathrm{g})$ & $17.23 \pm 0.39^{\mathrm{a}}$ & $17.69 \pm 0.29^{\mathrm{a}}$ & $14.60 \pm 0.29^{\mathrm{b}}$ & $14.43 \pm 0.57^{\mathrm{b}}$ \\
Rise in dough $(\mathrm{cm})$ & $4.12 \pm 0.16^{\mathrm{a}}$ & $3.57 \pm 0.05^{\mathrm{b} . \mathrm{c}}$ & $3.83 \pm 0.10^{\mathrm{a} . \mathrm{b}}$ & $3.37 \pm 0.12^{\mathrm{c}}$ \\
\hline
\end{tabular}

Different letters in lines differ statistically at $5 \%$ probability by Tukey's test ( $\mathrm{p} \pm 0.05$ ). Standard: with HPMC; T1: $2.5 \%$ chia; T2: $5.0 \%$ chia; T3: 7.5\% chia.

Table 3. Average scores for the characteristics of color, aroma, flavor, texture and appearance for samples of gluten-free breads with added chia flour and without gum.

\begin{tabular}{lcccc}
\hline \multicolumn{1}{c}{ Attributes } & Standard & T1 & T2 & T3 \\
\hline Color & $5.16 \pm 1.17^{\mathrm{a}}$ & $4.98 \pm 1.02^{\mathrm{a}, \mathrm{b}}$ & $4.52 \pm 1.20^{\mathrm{b}}$ & $4.64 \pm 1.21^{\mathrm{a}, \mathrm{b}}$ \\
Aroma & $4.70 \pm 1.23^{\mathrm{a}}$ & $4.82 \pm 1.17^{\mathrm{a}}$ & $4.36 \pm 1.35^{\mathrm{a}, \mathrm{b}}$ & $4.02 \pm 1.15^{\mathrm{b}}$ \\
Flavor & $4.46 \pm 1.49^{\mathrm{a}, \mathrm{b}}$ & $4.68 \pm 1.54^{\mathrm{a}}$ & $3.66 \pm 1.66^{\mathrm{b}, \mathrm{c}}$ & $3.62 \pm 1.54^{\mathrm{c}}$ \\
Texture & $4.96 \pm 1.34^{\mathrm{a}, \mathrm{b}}$ & $5.40 \pm 1.05^{\mathrm{a}}$ & $5.14 \pm 1.30^{\mathrm{a}, \mathrm{b}}$ & $4.64 \pm 1.32^{\mathrm{b}}$ \\
Appearance & $5.36 \pm 1.10^{\mathrm{a}, \mathrm{b}}$ & $5.48 \pm 1.16^{\mathrm{a}}$ & $4.76 \pm 1.17^{\mathrm{b}, \mathrm{c}}$ & $4.52 \pm 1.28^{\mathrm{c}}$ \\
\hline
\end{tabular}

Different letters in lines differ statistically at $5 \%$ probability by Tukey's test ( \pm \pm 0.05$)$. Standard: with HPMC; T1: $2.5 \%$ chia; T2: $5.0 \%$ chia; T3: $7.5 \%$ chia. Score: $1=$ greatly disliked; $2=$ disliked a lot; $3=$ disliked; $4=$ indiferent; $5=$ liked; $6=$ liked a lot; $7=$ very much liked. 
results were found by Pereira et al. (2013), when preparing potato breads with chia flour; they found higher values for intent to purchase for the formulations with lower percentages of chia.

\section{Conclusion}

The bread made with $2.5 \%$ chia flour, replacing rice and soy flours, behaved similarly to HPMC gum regarding the physical and sensory characteristics of bread; the specific volume of this formulation most resembled the standard. In terms of sensory evaluation, the acceptance testing showed that the bread with $2.5 \%$ chia flour showed no difference from the standard and presented the highest value for purchase intent. Therefore, it can be considered that the addition of chia flour represents a promising alternative in order to improve the physical and sensory characteristics of gluten-free breads, and also to replace gum.

\section{Acknowledgements}

The authors would like to thank the Higher Education Personnel Improvement Coordination (CAPES) for supporting this study and Favarin \& Co. Ltd for providing the rice flour, which was an important raw material for the development of this study.

\section{References}

Andrade, A. A., Coelho, S. V., Malta, H. L., \& Jorge, M. N. (2011). Avaliação sensorial de panificação enriquecido com farinha de feijão branco para pacientes celíacos. Nutrir Gerais, 5, 727-739.

Atzingen, M. C. B. C. V., \& Silva, M. E. M. P. (2001). Inhame na formulação de pão sem glúten. Nutrire, 22, 33-48.

Borges, J. T. S., Pirozi, M. B., Paula, C. D., Ramos, D. L., \& Chaves, J. B. P. (2011). Caracterização físico-química e sensorial de pão de sal enriquecido com farinha integral de linhaça. Boletim do CEPPA, 29(1), 83-96.

Coelho, M. S., \& Salas-Mellado, M. M. (2015). Effects of substituting chia (Salvia hispânica L.) flour or seeds for wheat flour on the quality of the bread. LWT - Food Science and Technology, 60(2), 729-736. http://dx.doi.org/10.1016/j.lwt.2014.10.033.
El-Dash, A. A., Camargo, C. O., \& Diaz, N. M. (2006). Fundamentos da tecnologia de panificação (Tecnologia Agroindustrial, pp. 241-243). São Paulo: Secretaria da Indústria, Comércio, Ciência e Tecnologia.

Figueira, F. S., Crisel, T., Silva, C., \& Salas-Mellado, M. (2011). Pão sem glúten enriquecido com microalga Spirulinaplatensis. Brazilian Journal of Food Technology, 14(4), 308-316. http://dx.doi.org/10.4260/ BJFT2011140400037.

Garda, M. R., Alvarez, M., Lattanzio, M., Ferraro, C., \& Colombo, M. (2012). Rol de los hidrocoloides de semillas de chía y lino en la optimización de panificados libres de glúten. Diaeta, 30(140), 31-38.

Katina, K., Salmenkallio-Marttila, M., Partanen, R., Forssell, P., \& Autio, K. (2006). Effects of sourdough and enzymes on staling of high-fibre wheat bread. LWT - Food Science and Technology, 39(5), 479-491. http://dx.doi.org/10.1016/j.lwt.2005.03.013.

Moreira, M. R. (2007). Elaboração de pré-mistura para pão sem glúten para celíacos (Master's dissertation). Universidade Federal de Santa Maria, Santa Maria.

Pereira, B. D. S., Pereira, B. D. S., Cardoso, É. D. S., Mendonça, J. O. B., Souza, L. B., Santos, M. P., Zago, L., \& Freitas, S. M. L.. (2013). Análise físico-química e sensorial do pão de batata isento de glúten enriquecido com farinha de chia. Demetra, 8(2), 125-136. http:// dx.doi.org/10.12957/demetra.2013.5646.

Philippi, S. T. (2003). Nutrição e técnica dietética (pp. 27-35). Barueri: Manole.

Pizzinatto, A., Magno, C. P. R., \& Campagnolli, D. M. F. (1993). Avaliação tecnológica de produtos derivados da farinha de trigo (pão, macarrão, biscoitos). Campinas: Centro de Tecnologia de Farinhas e Panificação, Instituto de Tecnologia de Alimentos. $54 \mathrm{p}$.

Rocha, L. S., \& Santiago, R. A. C. (2009). Implicações nutricionais e sensoriais da polpa e casca de baru (DipterixAlata vog.) na elaboração de pães. Ciência e Tecnologia dos Alimentos, 4(4), 820-825. http:// dx.doi.org/10.1590/S0101-20612009000400019.

Uribe, J. A. R., Perez, J., Kauil, H., Rubio, G., \& Alcocer, C. (2011). Extraction of oil from chia seeds with supercritical $\mathrm{CO}_{2}$. The Journal of Supercritical Fluids, 56(2), 174-178. http://dx.doi.org/10.1016/j. supflu.2010.12.007.

Vasconcelos, A. Z. C., Pontes, D. F., Garruti, D. S., \& Silva, A. P. V. (2006). Processamento e aceitabilidade de pães de forma a partir de ingredientes funcionais: farinha de soja e fibra alimentar. Alimentos e Nutrição, 17, 43-49. 